\title{
Article \\ Numerical and Experimental Investigation of Oil-Guiding Splash Lubrication in Light Helicopter's Reducers
}

\author{
Mei Yin ${ }^{1,2}$, Xi Chen ${ }^{1}$, Yu Dai ${ }^{1, *}$, Duan Yang ${ }^{2}$, Lanjin $X^{2}{ }^{2}$ and Xiang Zhu ${ }^{1}$ (D) \\ 1 College of Mechanical and Electrical Engineering, Central South University, Changsha 410083, China; \\ yinzhuifeng@126.com (M.Y.); 213712157@csu.edu.cn (X.C.); zhuxiang2017@csu.edu.cn (X.Z.) \\ 2 Hunan Aviation Powerplant Research Institute, AECC, Zhuzhou 412002, China; \\ yangd892021@163.com (D.Y.); lansama@live.com (L.X.) \\ * Correspondence: 210143@csu.edu.cn
}

check for

updates

Citation: Yin, M.; Chen, X.; Dai, Y.; Yang, D.; Xu, L.; Zhu, X. Numerical and Experimental Investigation of Oil-Guiding Splash Lubrication in Light Helicopter's Reducers. Aerospace 2021, 8, 345. https:// doi.org/10.3390/aerospace 8110345

Academic Editor:

Christian Breitsamter

Received: 18 October 2021

Accepted: 12 November 2021

Published: 15 November 2021

Publisher's Note: MDPI stays neutral with regard to jurisdictional claims in published maps and institutional affiliations.

Copyright: (c) 2021 by the authors. Licensee MDPI, Basel, Switzerland. This article is an open access article distributed under the terms and conditions of the Creative Commons Attribution (CC BY) license (https:/ / creativecommons.org/licenses/by/ $4.0 /)$.

\begin{abstract}
Limited by the space and weight of the reducer, it is difficult to use traditional oil-jet lubrication and splash lubrication for a light helicopter, so an oil-guiding splash lubrication method is adopted as a research object in this paper. Firstly, the lubrication performance of the oil-guiding cylinder in the main reducer under different rotating speeds, oil levels, and flight attitudes is investigated based on the computational fluid dynamics (CFD) method. Then, a specific test rig is developed, and lubrication tests are carried out to verify the feasibility and correctness of the simulation. These results show that oil level, rotating speed, and flight attitude have a great influence on splash lubrication performance.
\end{abstract}

Keywords: splash lubrication; oil-guiding cylinder; computational fluid dynamics; numerical simulation

\section{Introduction}

Lubricating oil plays a crucial role in reducing the friction between gears and bearings, as well as carrying away heat to maintain transmission performance. Generally speaking, there are two conventional types of lubrication, namely jet and splash lubrication. The former is commonly used in the main gearbox of heavy-lift helicopters with a rotational speed of up to $20,000 \mathrm{r} / \mathrm{min}$, while the latter is adopted in the intermediate or tail gearbox at a speed of around $4000 \mathrm{r} / \mathrm{min}$. Limited by the space and weight of the main reducer, they are no longer applicable for light helicopters whose output rotational speed of the main reducer is less than $700 \mathrm{r} / \mathrm{min}$. Therefore, to reduce the space and complexity of the lubrication system, an oil-guiding splash lubrication method is introduced to guide the oil to the gears and bearings, as illustrated in Figure 1.

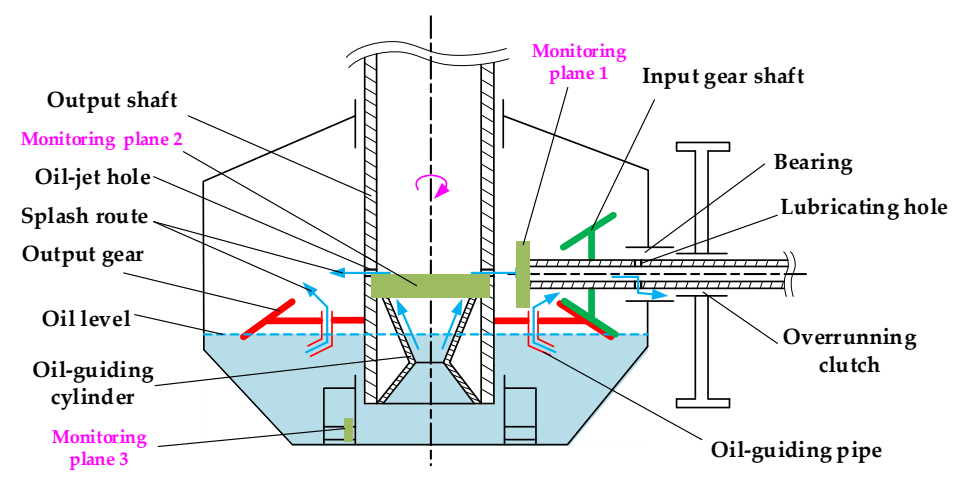

Figure 1. Schematic diagram of a helicopter main reducer oil-guiding splash lubrication system.

In terms of lubrication and cooling performance, flow field characteristics surrounding gears and no-load power losses (i.e., churning losses and windage losses) remain attractive 
areas for many scholars to study and research. On this research hotspot, experiments, theoretical investigations, and CFD investigations are the three main methods of determining the lubrication performance inside gearing systems. Recently, CFD methods have been regarded as reliable and effective tools for predicting flow field information [1-5]. Moshammer et al. [6] pioneered the use of CFD methods concerning the flow field inside a gearbox and validated their simulations by leveraging advanced photography and graphic technology to monitor the oil flow in a gearbox housing. Adopting CFD method, Concil and colleagues [7-9] studied the free surface and no-load power losses of gears partly immersed in an oil bath and compared these well with real operating conditions. Once again, CFD proved to be a powerful tool for engineers in design ideas and principles. Liu et al. [10-12] not only used the traditional finite volume method (FVM) (based on the Eulerian approach) but also exploited the smoothed particle hydrodynamics (SPH) method (based on the Lagrangian approach) to explore the oil churning behavior of a dip-lubricated gear pair. Their results indicated that comparisons of the oil distribution obtained by the SPH method with high-speed camera recordings inside the FZG efficiency gear test rig show good agreement, whereas they lack satisfactory precision in the estimation of churning losses. Hu et al. [13-15] investigated the churning losses of an intermediate spiral bevel gear housing of a helicopter around the same time by leveraging the FVM method and quantitatively analyzed the impacts of the tilt angle and the oil-guiding device. Given the rotational speed, lubricant properties, gear parameters, and immersion depth, Changenet and colleagues [16-19] proposed and experimentally validated a series of formulas capable of accurately predicting churning losses, ranging from one pinion to a pinion-gear pair. On the basis of experiments, Dai et al. [20] raised an analytical model to estimate the churning losses of spiral bevel gears, particularly considering the influence of oil density and viscosity from low to moderate speeds. Recently, Lu et al. [21] found that the churning losses of spiral bevel gears under splash lubrication account for around $1.93 \%$ of the input power and determined a good range of rotational speed and oil immersion depth of the intermediate gearbox.

Alternatively, oil-jet lubrication is relatively common in the main gearbox of a helicopter. Slightly different from that in the topic of splash lubrication, the CFD approach has become mainstream in complex gas-oil mixtures surrounding rotating gears under jet lubrication. It is divided into two categories: oil distribution in the meshing zone and interaction between the oil-jet flow and the spinning gear, namely oil-jet losses. In the first sector, Wang et al. [22-24] distinguished the lubrication performance of high-speed spur gears between out-of-mesh lubrication and into mesh lubrication using CFD simulations and presented that the high-speed air flow driven by the spinning gear can seriously interfere with the oil-jet flow. Furthermore, Dai et al. [25-28] derived mathematical impingement depths for various types of gears to search for an optimal oil nozzle layout, selecting the oil volume fraction and total oil-air pressure as the target. The change trends of the depths are opposed to the experimental findings of the temperature tests, while the trends of the oil volume fraction and total oil-air pressure show good agreement with the experiments. In the second sector, Fondelli et al. [29-31] employed the sliding-mesh method and the VOF method to focus on the oil-jet gear interaction and the resisting moment of a rotating gear under jet lubrication. They further analyzed the effect of the oil-jet inclination angle on the moment. Recently, focusing on the oil-guiding cylinder in a lubricating system, Yin et al. [32] compared three types of oil-guiding cylinders to determine the paraboloid oil-free surface in the cylinder and calculated the pressure and velocity distributions via the CFD method. Wang et al. [33] monitored the wear failure status in the particles of lubricating oil to judge the bearing condition in turboshaft engines under oil injection lubrication conditions. In the propulsion of ultralight aircraft, Wróblewski $[34,35]$ concluded that the use of oils with low viscosity under high engine working temperature conditions is strictly governed by the rotational speeds of the shaft.

Previous research mainly paid attention to the no-load power losses or flow field characteristics of gearing systems under conventional splash lubrication or oil-jet lubrica- 
tion. In reality, the internal space of the main reducer in a light helicopter is not enough to hold an oil feeding system to realize the process of jet lubrication, while conventional splash lubrication needs the gear partly immersed into the oil sump in contradiction with the structure of the gearbox, as shown in Figure 1. Therefore, this paper introduces an oil-guiding splash lubrication system to drive the lubricant to reach the gears and bearings. Firstly, a numerical model of the special gearing system is developed to investigate the influence of different rotating speeds, oil levels, and flight attitudes using the CFD method. Secondly, a specific test rig is established for the oil-guiding splash lubrication tests to verify the accuracy and feasibility of the numerical method, which provides the theoretical foundation for the design practice of the main reducer in a light helicopter.

\section{CFD Methodology}

In analyzing the flow characteristics in the lubrication system with the aid of the CFD method, the governing equation, the turbulence model, CFD modeling, and grid technology are the most important and fundamental.

\subsection{Governing Equation}

Navier-Stokes equations can be expressed in vector form. For an incompressible fluid, namely when the density is constant, the vector equation is as follows:

$$
\rho \frac{D u}{D t}=-\nabla p+\mu \nabla^{2} u+F
$$

where $\rho, \mu$ are the fluid density and viscosity, respectively; $p$ connotes the hydrostatic pressure in the fluid element; $\nabla$ is the Nabla operator; and $\nabla^{2}$ denotes the Laplace operator.

In this paper, the $k$-epsilon turbulence model is adopted to study the fluid flow. The mathematical equations of the $k$-epsilon turbulence model include the k-equation (turbulent kinetic energy equation) and the epsilon equation (turbulent kinetic energy dissipation rate equation). The expression of the transfer equation of turbulent kinetic energy is

$$
\frac{\partial k_{T}}{\partial t}+\frac{1}{V_{F}}\left\{u A_{x} \frac{\partial k_{T}}{\partial x}+v A_{y} \frac{\partial k_{T}}{\partial y}+w A_{z} \frac{\partial k_{T}}{\partial z}\right\}=P_{T}+G_{T}+\operatorname{Diff}_{k_{T}}-\varepsilon_{T}
$$

where $V_{F}$ is the flowable volume fraction; $A_{x} A_{y} A_{z}$ represent the flow contact area fraction in the $x, y$, and $z$ directions, respectively; $P_{T}$ is the turbulent energy generation term; $G_{T}$ is the buoyancy term; Diff $k_{T}$ denotes the turbulent energy dispersion term; and $\varepsilon_{T}$ connotes the turbulent energy dissipation term.

The expression of the transfer equation of the dissipation rate of turbulent kinetic energy is

$$
\begin{aligned}
& \frac{\partial \varepsilon_{T}}{\partial t}+\frac{1}{V_{F}}\left\{u_{x} A_{x} \frac{\partial \varepsilon_{T}}{\partial x}+v A_{y} \frac{\partial \varepsilon_{T}}{\partial y}+w A_{z} \frac{\partial \varepsilon_{T}}{\partial z}\right\} \\
& =\frac{C D I S 1 \cdot \varepsilon_{T}}{k_{T}}\left(P_{T}+C D I S 3 \cdot G_{T}\right)+\operatorname{Diff}_{\varepsilon}-C D I S 2 \frac{\varepsilon_{T}^{2}}{k_{T}}
\end{aligned}
$$

where $\operatorname{Diff}_{\varepsilon}$ denotes the diffusion term of the dissipation rate of turbulent kinetic energy. CDIS1, CDIS2, and CDIS3 are dimensionless user tunable parameters. For the $k$-epsilon model, in our case, the default values for CDIS1, CDIS2, and CDIS3 are used.

\subsection{CFD Modeling}

In order to assure the CFD investigation, the actual three-dimensional structure of the oil-guiding splash lubrication system should be appropriately simplified and modeled.

\subsubsection{Oil-Guiding Cylinder and Oil-Guiding Splash Lubrication System}

As shown in Figure 1, the oil-guiding cylinder in the main reducer of a light helicopter is a double-tapered structure. The upper inverted taper angle is $35^{\circ}$, while the lower taper angle is $90^{\circ}$. The distance from the bottom of the oil-guiding cylinder to the bottom of the oil pool is $15 \mathrm{~mm}$. The three-dimensional model is established in Figure 2a. 
To simplify the simulation setup, improve the mesh quality, and reduce the computational load, the oil-guiding cylinder, rotor shaft, and bearing inner ring in Figure 1 are simplified and modeled as a part, the bearing support and bearing outer ring is modeled as a part, and the rolling element and cage are regarded as a part. The simplified geometric model is shown in Figure 2b.

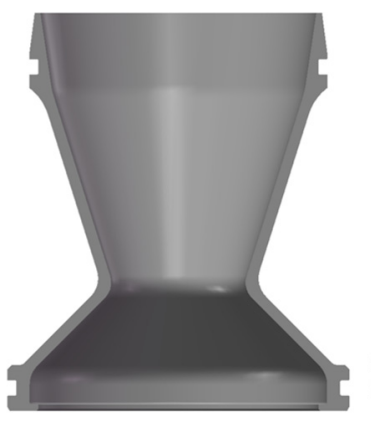

(a)

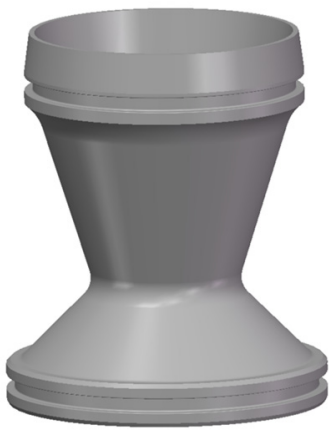

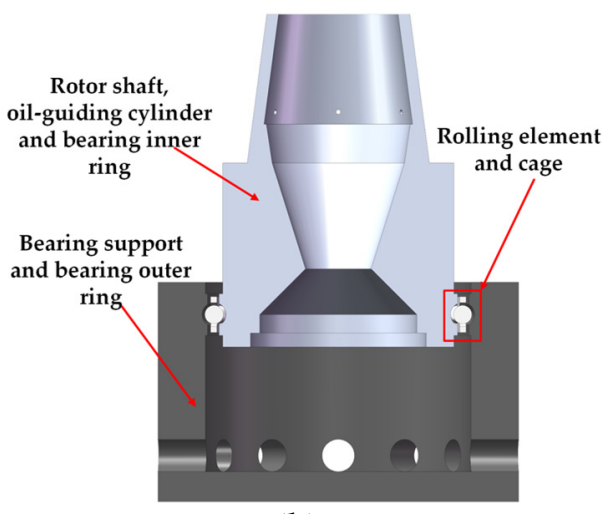

(b)

Figure 2. Three-dimensional modeling: (a) oil guide; (b) splash lubrication system.

\subsubsection{Flow Monitoring Plane}

To monitor the flow rate passing through the hollow shaft and determine the performance of the oil-guiding cylinder, three flow monitoring planes are defined with the parameters listed in Table 1 below.

Table 1. Parameters of monitoring plane.

\begin{tabular}{cccc}
\hline Monitoring Planes & $\boldsymbol{x}$-Direction $\mathbf{( m m )}$ & $\boldsymbol{y}$-Direction $\mathbf{( m m )}$ & $\boldsymbol{z}$-Direction $(\mathbf{m m})$ \\
\hline 1 & $x=70$ & $y_{\mathrm{L}}=-15, y_{\mathrm{H}}=15$ & $z_{\mathrm{L}}=105, z_{\mathrm{H}}=135$ \\
2 & $x_{\mathrm{L}}=-33, x_{\mathrm{H}}=33$ & $y_{\mathrm{L}}=-33, y_{\mathrm{H}}=33$ & $z=113$ \\
3 & $x=-70$ & $y_{\mathrm{L}}=-8, y_{\mathrm{H}}=8$ & $z_{\mathrm{L}}=-38, z_{\mathrm{H}}=-22$ \\
\hline
\end{tabular}

\subsection{CFD Grid Technology}

The fractional area/volume obstacle method is very effective for incorporating geometric effects into the governing equations. Like all discrete methods, it is still severely limited by the resolution of the computational grid. In this paper, the calculation domain of fluid for the oil-guiding cylinder is divided into uniform hexahedral mesh types, and the oil bath of $200 \mathrm{~mm}$ in length, $200 \mathrm{~mm}$ in width, and $105 \mathrm{~mm}$ in height is established to avoid the interference caused by insufficient oil supply. The number of total cells is set to $4,000,000$, as shown in Figure 3. The number of total cells in the fluid domain under this mesh generation scheme is $4,012,910$, and the mesh quality is good.
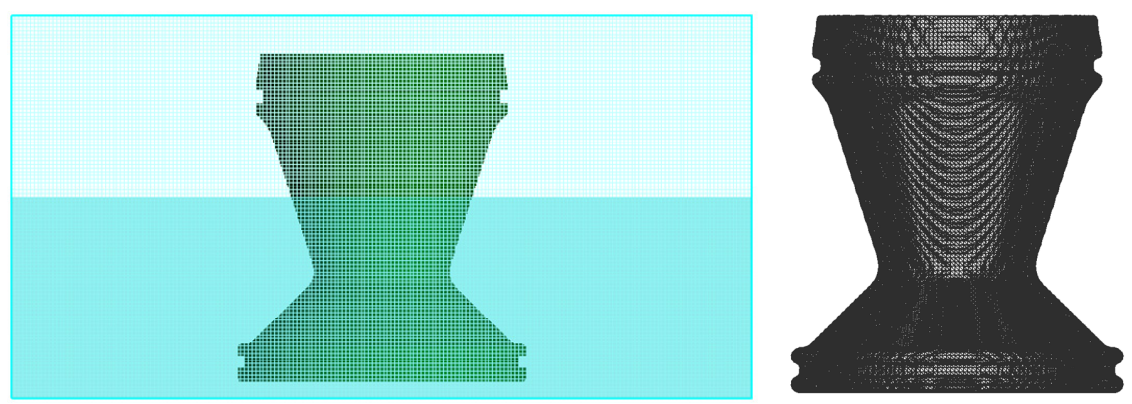

Figure 3. Grid of the case. 
As for the CFD model of the oil-guiding splash lubrication system, the calculation domain of fluid is also divided into uniform hexahedral mesh types, and the oil bath of $200 \mathrm{~mm}$ in length, $200 \mathrm{~mm}$ in width, and $170 \mathrm{~mm}$ in height is developed. The calculation domain Block 1 from $-40 \mathrm{~mm}$ to $130 \mathrm{~mm}$ is regarded as an overall grid zone. The oil-jet hole domain Block 2 of $80 \mathrm{~mm}$ in length, $80 \mathrm{~mm}$ in width, and 116.5-121 $\mathrm{mm}$ in height is locally refined. The size of cells is $1 \mathrm{~mm}$. The number of total cells and local refined cells is set to $8,000,000$ and 500,000 , respectively. After this mesh generation scheme, the actual number of total cells in the fluid domain is 8,483,447, and the number of Blocks 1 and 2 is $7,969,259$ and 514,188 , respectively. The maximum adjacent cell size ratio in three directions in cartesian coordinates is 1 , and the mesh quality is good. The boundary type of mesh Block 1 is symmetrical. The implicit pressure solver and viscous stress solver are selected, the second-order algorithm is selected for momentum advection, and the momentum and continuity equations chosen in this paper are solved. The restart data interval is $0.1 \mathrm{~s}$, and the fraction interval is 0.1 . The maximum elapsed time interval is $10 \mathrm{~s}$.

To improve the precision and reliability of the CFD investigation results, a grid dependency test is performed. The aforementioned mesh generation scheme is exploited for the oil-guiding splash lubrication system, and the total cells $C$ is set to 3,000,000, $5,000,000,8,000,000$, and 10,000,000. The fluid resisting moment of the rotor shaft, bearing component, and the flow rate through flow Monitoring Plane 2 are taken as the standard of the grid independence test, and Figure 4 depicts the numerical results against the grid number. As shown in Figure 4, the number of total cells appears to have a small effect on the resisting moment of the rotor shaft. As the number is 5,000,000, the resisting moments of bearing components are close to that of $8,000,000$ and 10,000,000. As for the flow rate (scatter in Figure 4c) and its 10-point moving average value (line in Figure 4c) passing through Monitoring Plane 2, the flow rates are small, and the errors are large when the number of cells is $3,000,000$ or $5,000,000$, while the flow rates are very close with the maximum error less than $1.5 \mathrm{~mL} / \mathrm{s}$ when the number of cells is $8,000,000$ or $10,000,000$. Balancing the computational accuracy and computational load, the number of total cells in all simulations is set to 8 million in this paper. Aeroshell turbine engine oil 555, a synthetic ester lubricant, is used in this paper. Its density is $0.875 \mathrm{~g} / \mathrm{cm}^{3}$, and its viscosity is $0.0233 \mathrm{~kg} /(\mathrm{m} \cdot \mathrm{s})$ at $40{ }^{\circ} \mathrm{C}$.

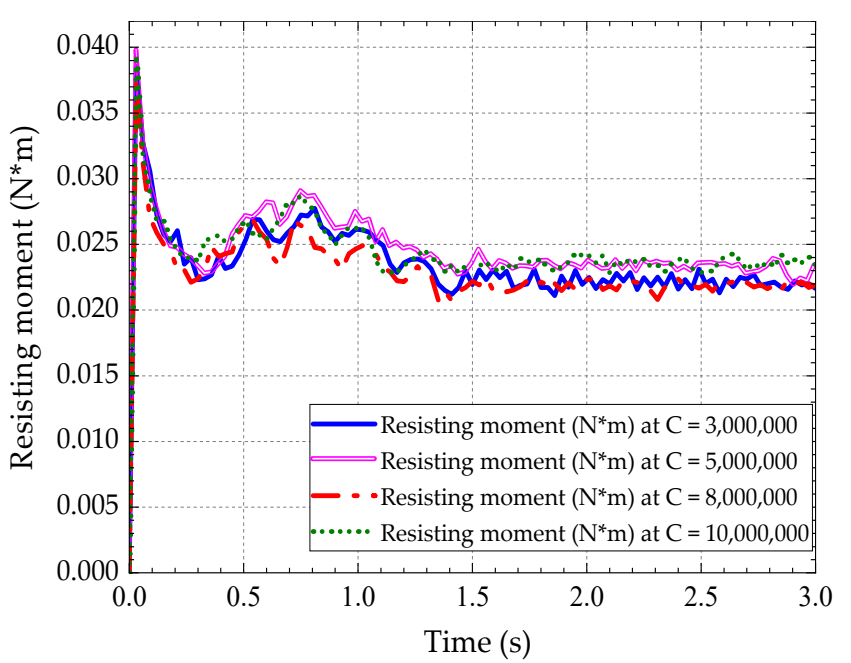

(a)

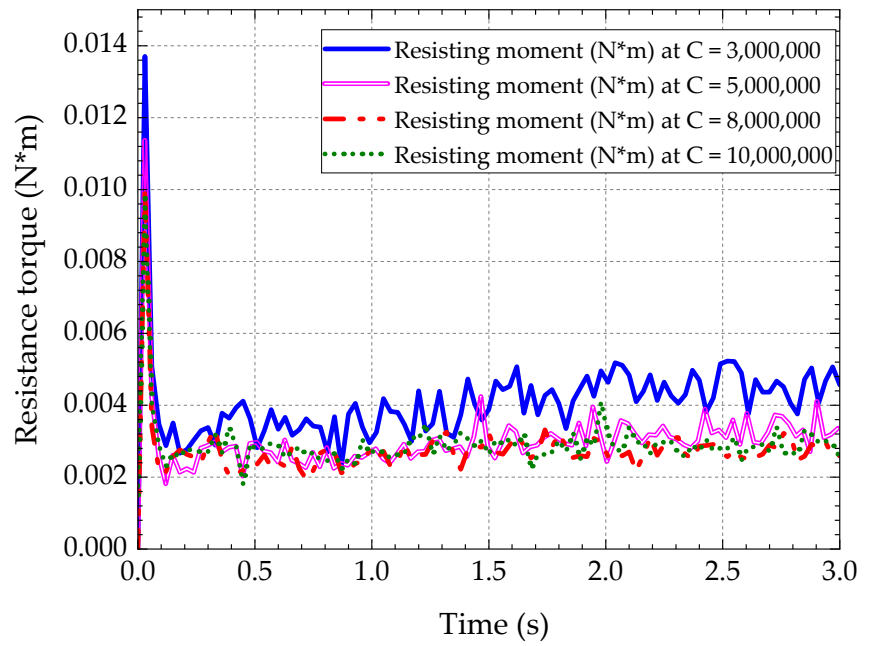

(b)

Figure 4. Cont. 


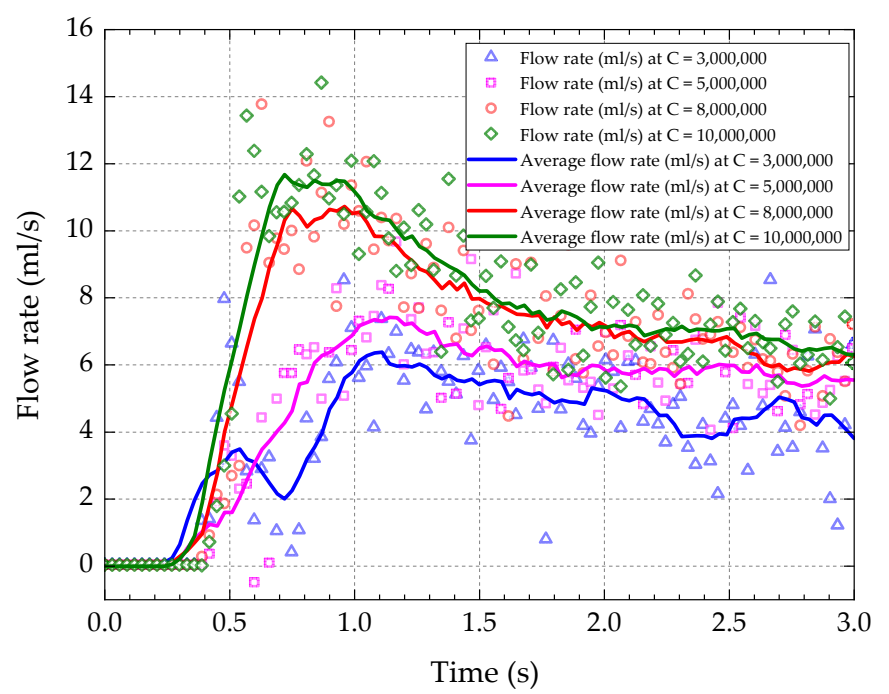

(c)

Figure 4. Resisting moment and flow rate-time curves against total cells: (a) resisting moment of rotor shaft; (b) resisting moment of bearing components; (c) flow rate and its 10-point moving average value (Monitoring Plane 2).

\section{Numerical Results}

In this paper, the influences of typical working conditions, including rotational speed, flight inclination, and oil level on the lubrication performance are mainly discussed.

\subsection{Rotational Speed}

To analyze the effect of rotational speed on the oil supply of the oil-guiding cylinder, the rotational speed $n$ of the rotor shaft is set to $400 \mathrm{r} / \mathrm{min}, 530 \mathrm{r} / \mathrm{min}$, and $660 \mathrm{r} / \mathrm{min}$. The fluid resisting moment of the rotor shaft and the oil-guiding cylinder is obtained as in Figure 5. It can be seen from the curve that the rotational speed has a strong impact on the fluid resisting moment. The higher the speed, the larger the fluid resisting moment.

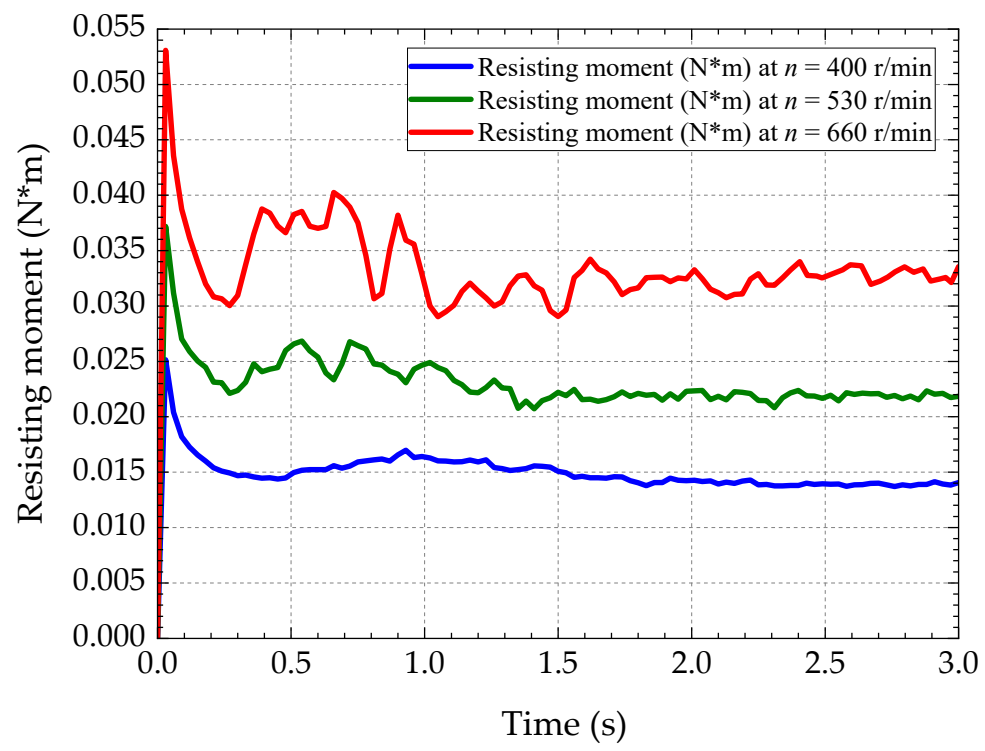

Figure 5. Fluid resisting moment-time curve.

Meanwhile, Figure 6 depicts the change trends of the flow rate (scatter in Figure 6) and its 10-point moving average value (line in Figure 6) passing through flow Monitoring Plane 2 under three different rotational speeds. From the figure, it can be seen that it is extremely difficult for the lubricating oil to reach the top of the oil-guiding cylinder at $400 \mathrm{r} / \mathrm{min}$, and 
the flow rate is close to zero. Compared with the rotational speed of $530 \mathrm{r} / \mathrm{min}$, the oil reaches the top sooner than that of $660 \mathrm{r} / \mathrm{min}$, and the peak of the flow rate is approximately $20 \mathrm{~mL} / \mathrm{s}$ at about $0.6 \mathrm{~s}$, while the peak value at $530 \mathrm{r} / \mathrm{min}$ just surpasses $1 \mathrm{~mL} / \mathrm{s}$ at $0.7 \mathrm{~s}$. After $1.5 \mathrm{~s}$, the variation tendency of the flow rate at $660 \mathrm{r} / \mathrm{min}$ is much closer to that at $530 \mathrm{r} / \mathrm{min}$, and the average flow rate at $660 \mathrm{r} / \mathrm{min}$ is still higher than that at $530 \mathrm{r} / \mathrm{min}$.

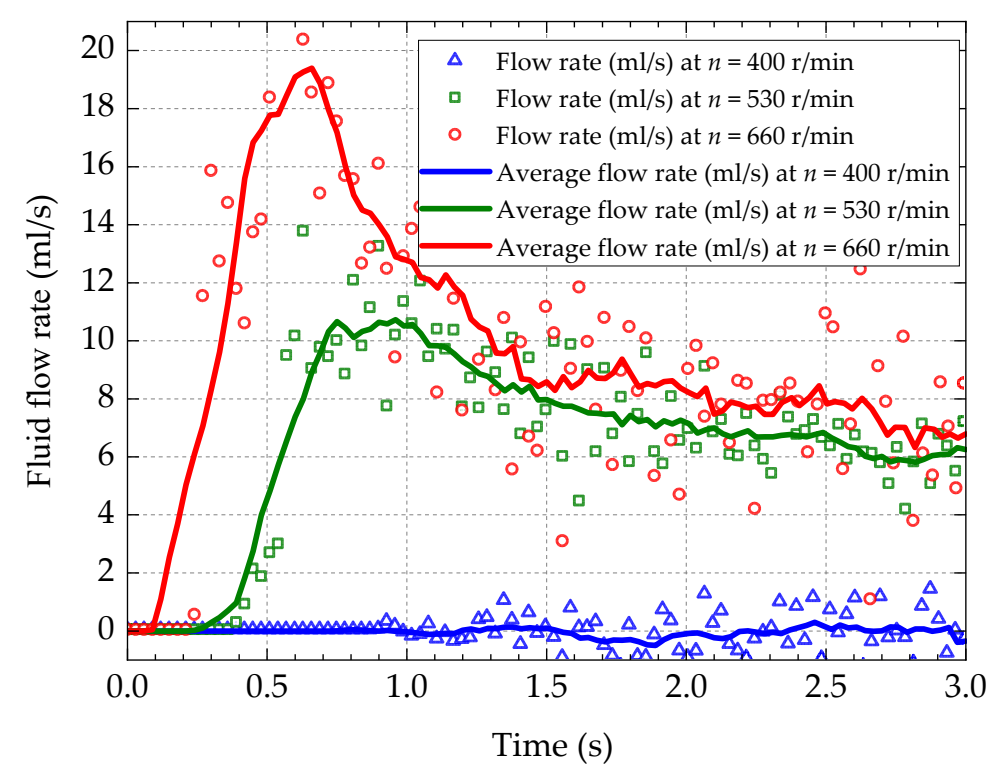

Figure 6. Oil flow rate-time curve (Monitoring Plane 2).

For the variation law of the flow rate in the interlocking pore near the bottom of the oil bath, it can be obtained by monitoring the flow rate variation through Plane 3 with time, as is shown in Figure 7. Clearly, the higher the rotational speed, the more intense the flow fluctuation in the interlocking pore, and at the same time, the higher the average value of the flow rate after $1.5 \mathrm{~s}$ is.

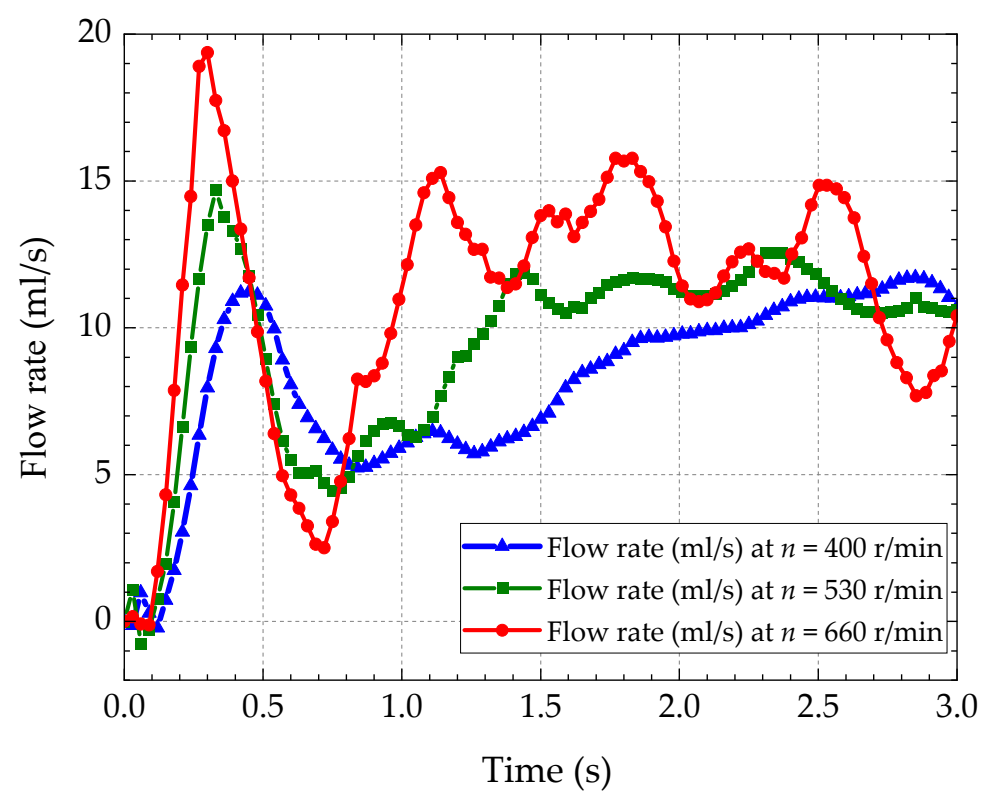

Figure 7. Oil flow rate-time curve (Monitoring Plane 3).

In addition, the flow rate (scatter in Figure 8) and its integration (oil volume) (line in Figure 8) passing through flow Monitoring Plane 1 under three different rotational 
speeds against time are shown in Figure 8. The two means the lubricating oil flows through Plane 1 and reaches the input gear, bearings, and spline. The oil volume at $530 \mathrm{r} / \mathrm{min}$ and $660 \mathrm{r} / \mathrm{min}$ shows a similar trend and slopes, except for time dilation, whereas at $400 \mathrm{r} / \mathrm{min}$, the amount of oil reaching the top of the oil-guiding cylinder is very low, resulting in very little oil passing through Monitoring Plane 1, and the total oil volume is close to zero in this case.

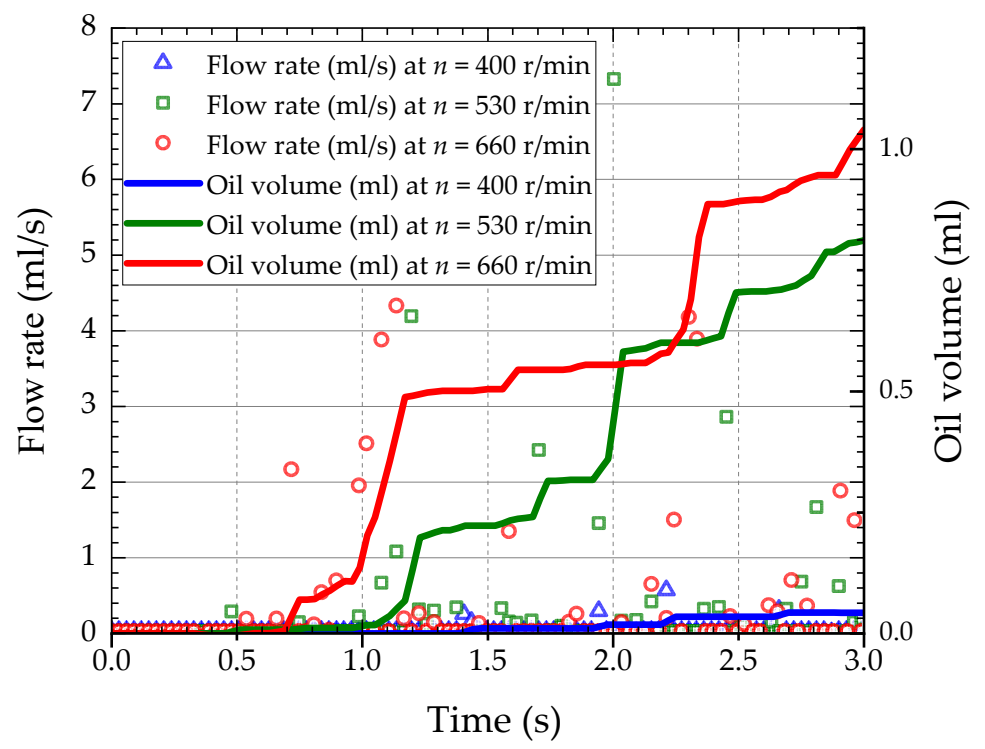

Figure 8. Oil flow rate-oil volume-time curve (Monitoring Plane 1).

The total oil volume flowing through each monitoring plane obtained by numerical analysis under different speeds is listed in Table 2. The higher the rotational speed, the more the oil volume through the monitoring plane. As for Monitoring Plane 1, the amount of oil at $400 \mathrm{r} / \mathrm{min}$ is very small. For Monitoring Plane 2, the total amount of oil reaching the top of the oil-guiding cylinder at $660 \mathrm{r} / \mathrm{min}$ is significantly increased compared with that of $530 \mathrm{r} / \mathrm{min}$. For Monitoring Plane 3, the increase in speed is beneficial to the increase in the total amount of oil passing through the interlocking pore. From the above analysis, it can be seen that there is a critical speed between $400 \mathrm{r} / \mathrm{min}$ and $530 \mathrm{r} / \mathrm{min}$ for oil supply to the oil-guiding cylinder, beyond which the oil can climb to the top of the cylinder in large quantities; otherwise, the lubricating oil will not reach it.

Table 2. Total oil volume through the monitoring planes versus rotational speed.

\begin{tabular}{cccc}
\hline $\begin{array}{c}\text { Rotating Speed } \\
(\mathbf{r} / \mathbf{m i n})\end{array}$ & $\begin{array}{c}\text { Oil Volume of } \\
\text { Monitoring Plane 1 } \\
(\mathbf{m L})\end{array}$ & $\begin{array}{c}\text { Oil Volume of } \\
\text { Monitoring Plane 2 } \\
(\mathbf{m L})\end{array}$ & $\begin{array}{c}\text { Oil Volume of } \\
\text { Monitoring Plane 3 } \\
(\mathbf{m L})\end{array}$ \\
\hline 400 & 0.043 & 0.11 & 24.40 \\
530 & 0.82 & 19.66 & 28.24 \\
660 & 1.04 & 28.97 & 33.10 \\
\hline
\end{tabular}

\subsection{Flight Inclination}

To describe the helicopter flight attitude, Figure 9 defines the positive direction of the flight pitch and roll angles by the right-hand rule. In this case, the main reducer of a helicopter is positioned as shown in Figure 9, with the positive direction of the input shaft pointing from the tail to the nose. 

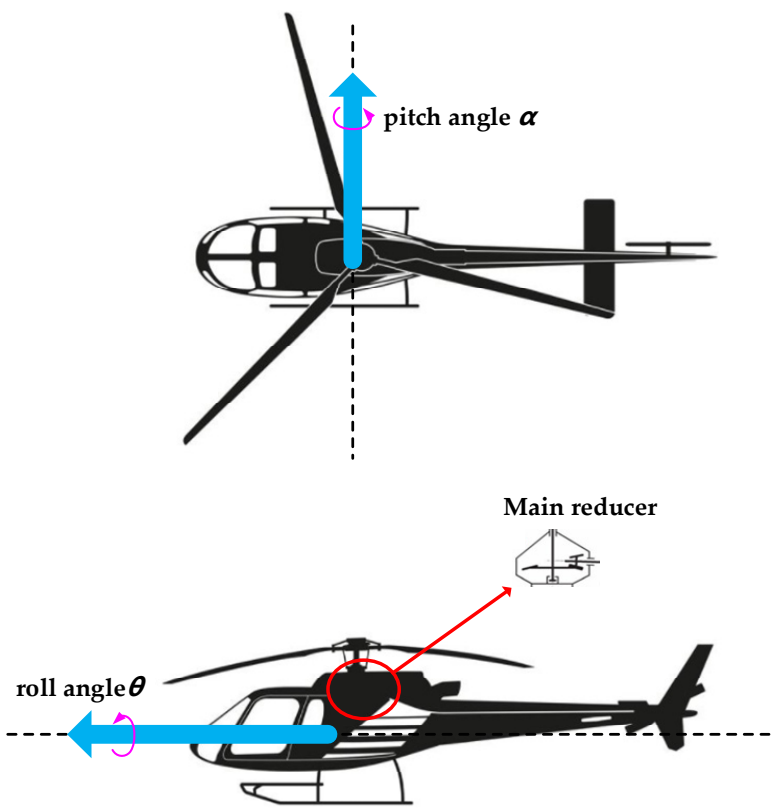

Figure 9. Definition of flight pitch and roll angles.

A numerical model with a pitch angle of $\alpha= \pm 15^{\circ}$ and roll angle of $\theta= \pm 15^{\circ}$ is established, and the flow rate and its corresponding integration (oil volume) through Monitoring Plane 1 are obtained as Figure 10. Clearly, the flow rate at the pitch angle of $15^{\circ}$ is significantly higher than that at pitch angle $-15^{\circ}$, and the flow rate at a roll angle of $15^{\circ}$ is also significantly higher than that at a roll angle of $-15^{\circ}$. In other words, the total oil volume through the target area is more for a larger pitch angle or roll angle.

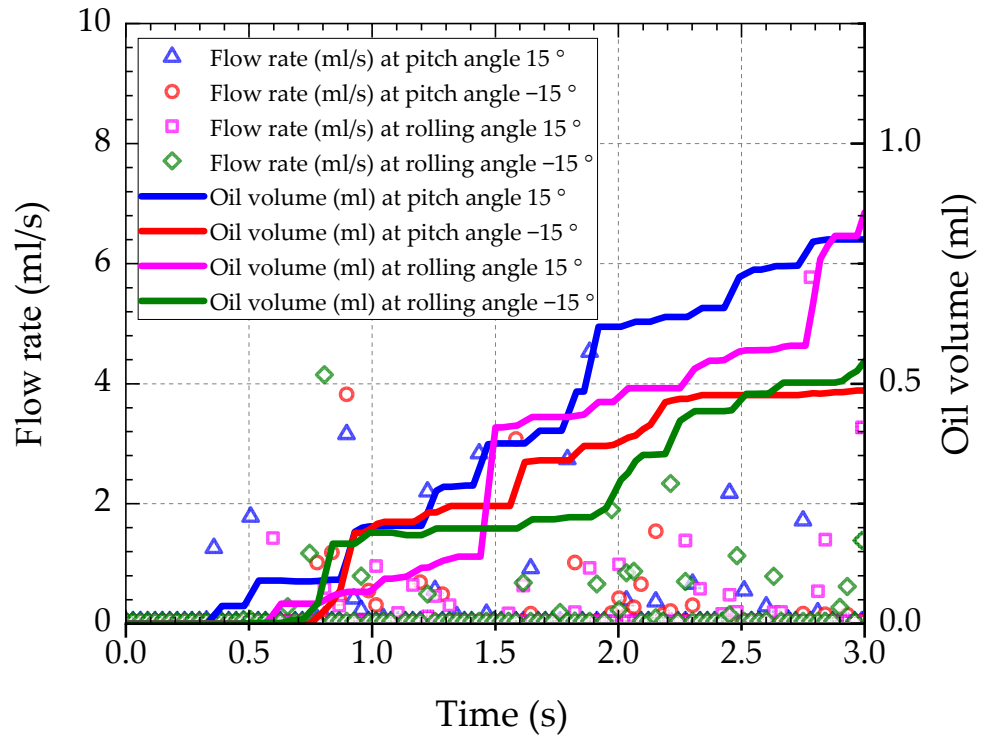

Figure 10. Flow rate-oil volume-time curves (Monitoring Plane 1).

Figure 11 shows the flow field distribution characteristic of the oil-guiding cylinder at the pitch angle of $15^{\circ}$ and at the moment of $1.5 \mathrm{~s}$. There is no obvious difference between the free liquid surface on both sides of the oil-jet hole, and the shape and thickness of the oil layer formed by the oil climbing along the inside wall of the oil-guiding cylinder are symmetrical about the axis of the rotor shaft. It is suggested that the difference in flow rate caused by the pitch angle and the roll angle is probably caused by gravity and rotation direction. When the oil-throwing direction is inclined to the direction of gravity, 
the splashed oil volume is greater. Meanwhile, as the rotor shaft rotates with an oil-jet hole moving from high to low, the splashed oil volume is more than that of moving from low to high.

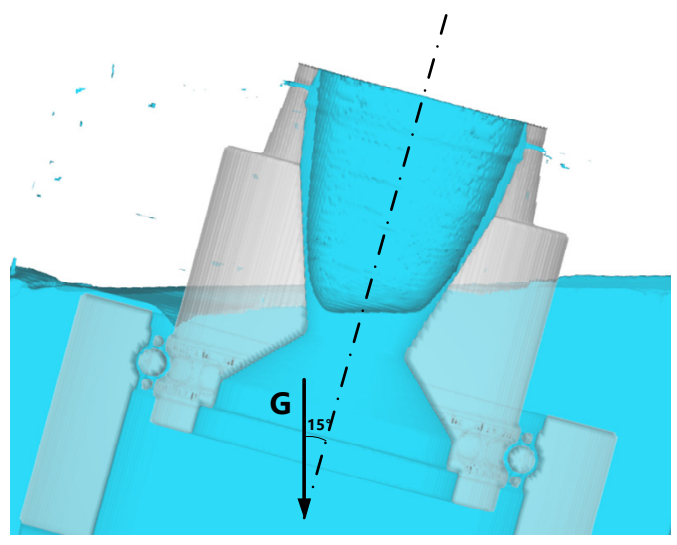

Figure 11. Cross-section of flow field distribution $\left(\alpha=15^{\circ}, t=1.5 \mathrm{~s}\right)$.

The total amount of oil passing through Monitoring Plane 1 at different flight attitude angles is obtained as shown in Table 3. When the oil-guiding splash lubrication system is tilted to the spin-in side, the amount of oil splashed to the hollow cavity of the input shaft is outstanding larger than that of the non-spin-in side, namely, when the main shaft is rotated counterclockwise and the airframe is tilted to the positive direction of the pitch angle and the positive direction of the roll angle, the effective splashed oil amount is greater. Compared with the flight attitude of $\alpha=0^{\circ}, \theta=0^{\circ}$, the oil feed volume in the target area at $\alpha=15^{\circ}, \theta=0^{\circ}$ and $\alpha=0^{\circ}, \theta=15^{\circ}$ is closer to that in the level posture. In these three operating conditions, the oil-guiding cylinder is capable of providing sufficient oil for splash lubrication and reaching the saturation value of oil volume under this oil-jet hole structure.

Table 3. Total oil quantity at different flight attitudes (Monitoring Surface 1).

\begin{tabular}{ccc}
\hline Parameters & Total Oil Volume $(\mathbf{m L})$ & Direction of Tilt \\
\hline$\alpha=15^{\circ}, \theta=0^{\circ}$ & 0.80041 & Spin-in side \\
$\alpha=-15^{\circ}, \theta=0^{\circ}$ & 0.48555 & Spin-out side \\
$\alpha=0^{\circ}, \theta=0^{\circ}$ & 0.81169 & Level \\
$\alpha=0^{\circ}, \theta=15^{\circ}$ & 0.85675 & Spin-in side \\
$\alpha=0^{\circ}, \theta=-15^{\circ}$ & 0.54695 & Spin-out side \\
\hline
\end{tabular}

\subsection{Oil Level}

To discuss the effect of oil level on the oil supply performance of the oil-guiding cylinder, the oil level height $D$ is set to $50 \mathrm{~mm}, 55 \mathrm{~mm}$, and $60 \mathrm{~mm}$. The time curves of the fluid resisting moment of the rotor shaft and oil-guiding cylinder are as shown in Figure 12. The change trends of the fluid resisting moment with time are basically the same for different oil levels, but the contact area of the cylinder with lubricating oil also depends on oil level heights, resulting in a slight difference of fluid resisting moment, and to be more detailed, the higher the oil level, the larger the fluid resisting moment. 


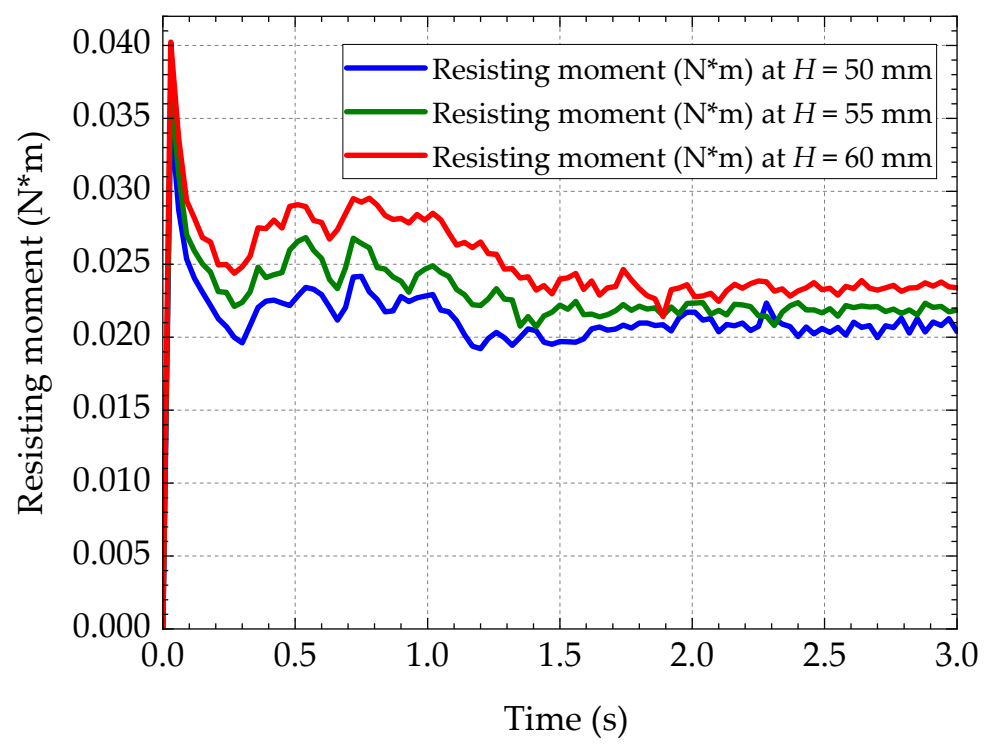

Figure 12. Change rules of fluid resisting moment versus time.

The flow rate (scatter in Figure 13) and its 10-point moving average value (line in Figure 13) passing through flow Monitoring Plane 2 are given in Figure 13. At an oil level of $55 \mathrm{~mm}$ and $60 \mathrm{~mm}$, the oil reaches the top of the oil-guiding cylinder at about $0.3 \mathrm{~s}$, and then the flow continues to rise to reach a peak and slowly decreases to be stable. Although the peak of the average flow rate varies greatly, the average flow rate is basically the same when the flow reaches relative stability at about $1.5 \mathrm{~s}$, while for the oil level of $50 \mathrm{~mm}$, the moment that the oil reaches the top, and the peak appears inclines to delay for the oil level of $50 \mathrm{~mm}$. Additionally, the flow rate is clearly lower than that of $55 \mathrm{~mm}$ and $60 \mathrm{~mm}$.

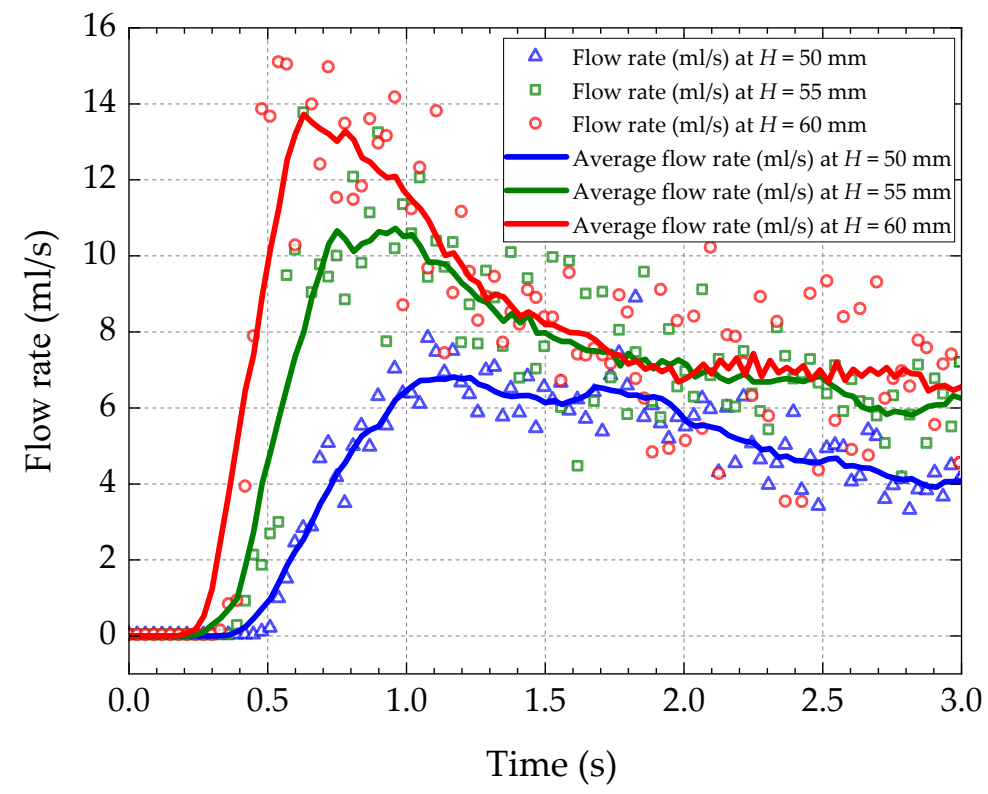

Figure 13. Change rules of flow rate moment versus time (Monitoring Plane 2).

As for the fluid field characteristics of the interlocking pore near the bottom, it can be obtained by Monitoring Plane 3 with time, as shown in Figure 14. The flow rate tends to be stable after a fleeting fluctuation. A higher oil level brings a greater fluctuation before $1.5 \mathrm{~s}$, as well as a greater flow rate after $1.5 \mathrm{~s}$. Furthermore, the flow rate and its corresponding time integral (oil volume) flowing through Monitoring Plane 1 are shown in Figure 15. The curves of oil volume at oil levels $55 \mathrm{~mm}$ and $60 \mathrm{~mm}$ have similar trends and slopes, whereas 
at $50 \mathrm{~mm}$, the oil volume grows more slowly, and the total oil volume is significantly lower than other high oil levels.

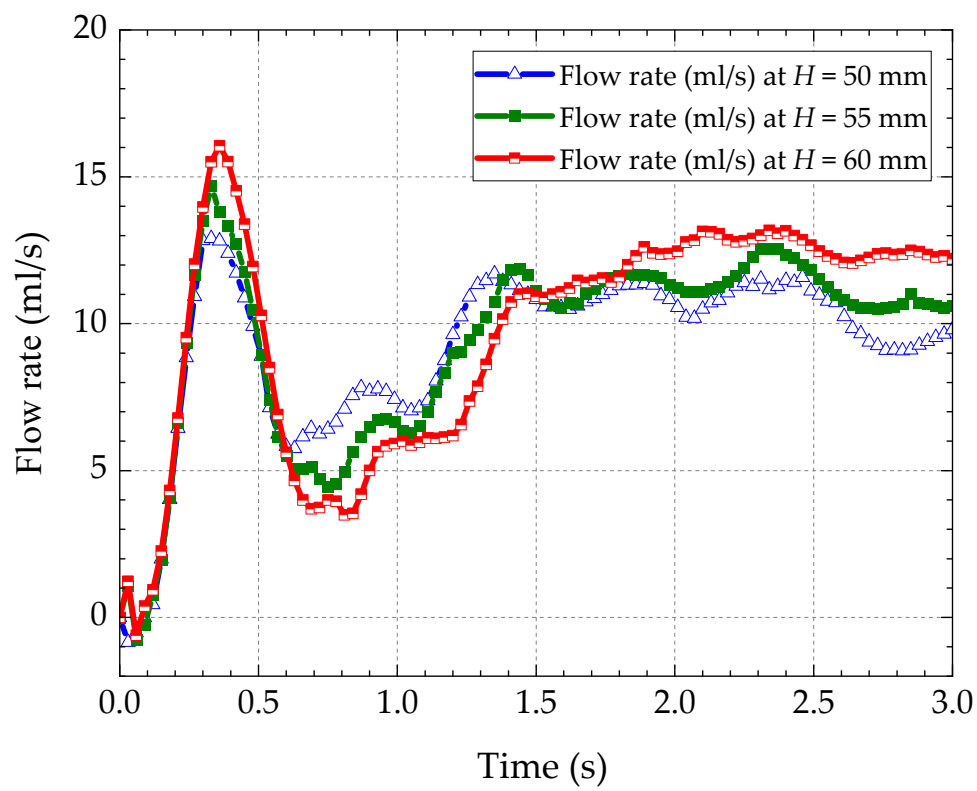

Figure 14. Change rules of flow rate moment versus time (Monitoring Plane 3).

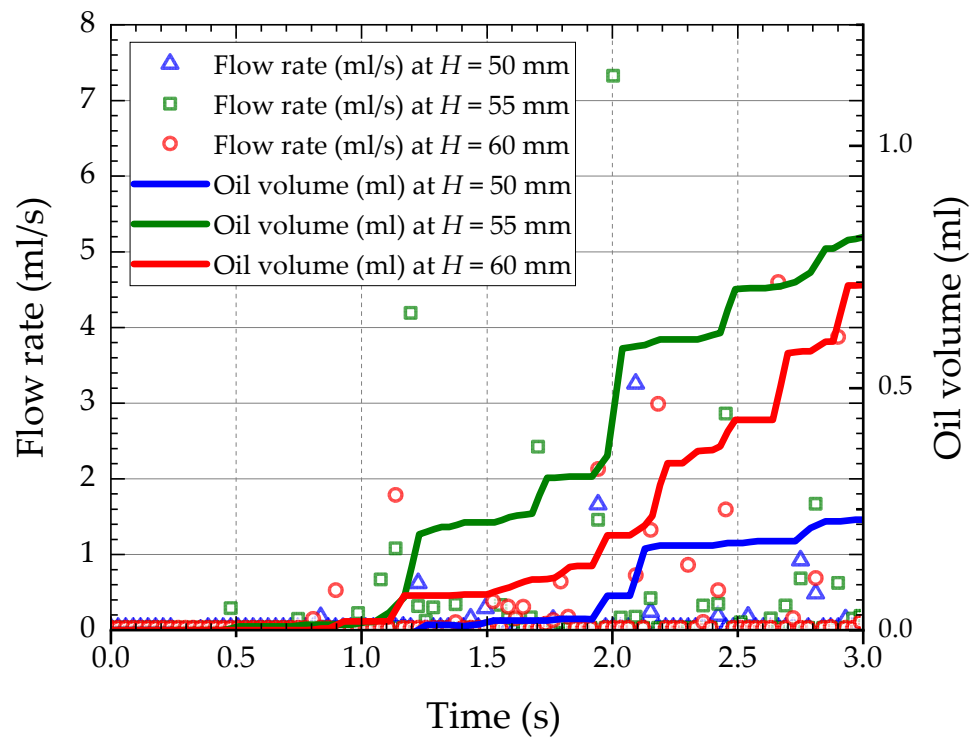

Figure 15. Change rules of flow rate and oil volume versus time (Monitoring Plane 1).

The total oil volume through the flow monitoring plane is further analyzed as listed in Table 4 . When the oil level rises, the oil volume of Monitoring Plane 2 changes significantly, while the oil volume of Monitoring Plane 3 is almost unchanged. This means that the oil level has an important effect on the amount of oil passing through the top plane of the oil-guiding cylinder. However, once the oil level drops from $55 \mathrm{~mm}$ to $50 \mathrm{~mm}$, the total amount of oil passing through Monitoring Plane 1 decreases from $0.81 \mathrm{~mL}$ to $0.23 \mathrm{~mL}$, and the amount of splashed oil reduces. Meanwhile, as the oil level is $55 \mathrm{~mm}$ and $60 \mathrm{~mm}$, the amount of oil flowing to the target area is relatively close. In terms of the oil supply at the top of the oil-guiding cylinder, the oil volume increases with the oil level, but the splashed oil volume does not increase significantly. This is due to the oil volume passing through the hole close to the saturation state at this point. 
Table 4. Total oil volume versus oil level.

\begin{tabular}{cccc}
\hline Oil Level $\mathbf{( m m )}$ & $\begin{array}{c}\text { Oil Volume of } \\
\text { Monitoring Plane 1 } \\
(\mathbf{m L})\end{array}$ & $\begin{array}{c}\text { Oil Volume of } \\
\text { Monitoring Plane 2 } \\
(\mathbf{m L})\end{array}$ & $\begin{array}{c}\text { Oil Volume of } \\
\text { Monitoring Plane 3 } \\
(\mathbf{m L})\end{array}$ \\
\hline 50 & 0.23 & 13.12 & 27.68 \\
55 & 0.81 & 19.66 & 28.24 \\
60 & 0.71 & 22.91 & 29.19 \\
\hline
\end{tabular}

\section{Experimental Validation}

To verify the reliability and effectiveness of the aforementioned CFD method, the test of oil-guiding splash lubrication under different operating conditions, including speed and oil level is carried out, and the reliability and effectiveness of CFD method are compared and verified by capturing the flow field distribution and monitoring the oil volume.

\subsection{Test Rig}

The oil-guiding splash lubrication test system consists of a drive motor, a drive system, a testing device, and a testing and controlling system. The drive motor drives the input hollow shaft of the test bevel gearbox through a coupling. The shaft is radially positioned with the bevel gear choosing interference fit, and a removable oil guide tube is installed on the driven gear spoke. The oil-guiding cylinder is positioned inside the hollow shaft by a snap ring, and three oil-jet holes are opened at the top of the hollow shaft and throughout the oil-guiding cylinder. The oil-collecting pipe is installed on the gearbox cover to collect the lubricant oil supplied by the oil-guiding cylinder to flow through the oil-jet hole. The lubricant is collected and measured through the measuring cup below the oil-collecting pipe. The photos of the lubrication test bench have been showed in detail in the open literatures [32].

\subsection{Experimental Results}

Balancing the experimental conditions and purposes, this paper mainly carried out tests under different rotational speeds and oil levels.

\subsubsection{Rotational Speed}

Considering the structural demands and operating conditions of the light helicopter, combining the analysis of numerical results that the flow rate is moderate at the oil level height $H$ of $55 \mathrm{~mm}$, lubrication tests were performed with the oil level height $H$ of $55 \mathrm{~mm}$, rotational speed $n$ of $400 \mathrm{r} / \mathrm{min}, 530 \mathrm{r} / \mathrm{min}$, and $660 \mathrm{r} / \mathrm{min}$, and running time for each test of $5 \mathrm{~min}$. The initial baseline testing was done without an oil-guiding cylinder inside the hollow shaft under each rotational speed or oil level. All measured experimental and numerical flow data are compared in Table 5. It is indicated that after increasing the speed, the splash of oil was more intense, the oil-collecting pipe collected a large amount of splash of oil not through an oil-jet hole, and the increase in speed contributed to increasing the splash of oil to the target area. At low speed, the increase in the experimental oil volume with the speed is larger than the corresponding simulation. This is due to the discrepancy between the simplified numerical model and the actual gearing system. Nevertheless, with the rotational speed of $400 \mathrm{r} / \mathrm{min}, 530 \mathrm{r} / \mathrm{min}$, and $660 \mathrm{r} / \mathrm{min}$, the error between the experimental net oil-collecting volume (i.e., target oil volume in Table 5) and the numerical oil volume is $20.0 \%, 13.6 \%$, and $9.2 \%$. Experiments show a good agreement with numerical results. It also verified the proposed CFD method is valid and effective. 
Table 5. Experimental and numerical flow data versus rotating speed.

\begin{tabular}{ccccccc}
\hline $\begin{array}{c}\text { Rotating Speed } \boldsymbol{n} \\
(\mathbf{r} / \mathbf{m i n})\end{array}$ & $\begin{array}{c}\text { RunningTime } \\
(\mathbf{m i n})\end{array}$ & $\begin{array}{c}\text { Experimental } \\
\text { Oil Volume (mL) }\end{array}$ & $\begin{array}{c}\text { Baseline } \\
\text { Testing Oil } \\
\text { Volume (mL) }\end{array}$ & $\begin{array}{c}\text { Target Oil } \\
\text { Volume (mL) }\end{array}$ & $\begin{array}{c}\text { Numerical Oil } \\
\text { Volume (mL) }\end{array}$ & $\begin{array}{c}\text { Error } \\
\text { (m) }\end{array}$ \\
\hline 400 & 5 & 0.5 & 0.4 & 0.1 & 0.12 & $20.0 \%$ \\
530 & 5 & 4.4 & 1.9 & 2.5 & 2.16 & $13.6 \%$ \\
660 & 5 & 10.2 & 7.7 & 2.5 & 2.27 & $9.2 \%$ \\
\hline
\end{tabular}

\subsubsection{Oil Level}

The rotational speed of $530 \mathrm{r} / \mathrm{min}$ is maintained, and there is an oil level height $H$ change of $45 \mathrm{~mm}, 55 \mathrm{~mm}$, and $65 \mathrm{~mm}$. The running time of each test is still $5 \mathrm{~min}$. All measured experimental and numerical flow data are compared in Table 6. Three oil level heights corresponded to the low, medium, and high oil levels, and the collection of oil volume at high oil levels was larger, reaching $17.3 \mathrm{~mL}$. There was no obvious splash of oil in the oil-jet hole at low oil level, while the splash of oil was intense at a high oil level, but most of the oil that splashed into the oil-collecting pipe came from the churning behavior of the shaft and gear. Both numerical and experimental data show that the amount of oil in the target area increases with the oil level. The rotating gear churns the oil very violently, so a higher oil level height contributes to more oil splashed from the gear surface into the oil-collecting tube, along with a larger amount of disturbed oil volume, namely, the amount of oil in the baseline testing increases with the increase in oil level. Nevertheless, with the oil level of $45 \mathrm{~mm}, 55 \mathrm{~mm}$, and $65 \mathrm{~mm}$, the error between the experimental net oil-collecting volume (i.e., target oil volume in Table 6) and the numerical oil volume is $10.0 \%, 13.6 \%$, and $12.6 \%$. Again, the experiments show good matching with the numerical results. It also verified the proposed CFD method is valid and effective. The results show that the increase in oil level or the increase in speed increases the amount of splashing oil.

Table 6. Experimental and numerical flow data versus oil level.

\begin{tabular}{ccccccc}
\hline $\begin{array}{c}\text { Oil Level } \boldsymbol{H} \\
(\mathbf{m m})\end{array}$ & $\begin{array}{c}\text { Running Time } \\
(\mathbf{m i n})\end{array}$ & $\begin{array}{c}\text { Experimental Oil } \\
\text { Volume }(\mathbf{m L})\end{array}$ & $\begin{array}{c}\text { Baseline Testing } \\
\text { Oil Volume }(\mathbf{m L})\end{array}$ & $\begin{array}{c}\text { Target Oil } \\
\text { Volume }(\mathbf{m L})\end{array}$ & $\begin{array}{c}\text { Numerical Oil } \\
\text { Volume }(\mathbf{m L})\end{array}$ & $\begin{array}{c}\text { Error } \\
\text { Volumer }\end{array}$ \\
\hline 45 & 5 & 0.7 & 0.6 & 0.1 & 0.09 & $10.0 \%$ \\
55 & 5 & 4.4 & 1.9 & 2.5 & 2.16 & $13.6 \%$ \\
65 & 5 & 17.3 & 14.2 & 3.1 & 3.49 & $12.6 \%$ \\
\hline
\end{tabular}

\section{Conclusions}

In this paper, a new type of lubrication system in the main reducer of a light helicopter is investigated. The effect of the oil-guiding cylinder on the lubrication performance of this special lubrication system under different operating conditions was analyzed. Meanwhile, lubrication tests were carried out by setting up a specific test rig for oil-guiding splash lubrication under different rotational speeds and oil levels. The difference between experimental oil volume and numerical results is less than $20.0 \%$ and no more than $14 \%$ for most of them. The main conclusions can be drawn as follows:

1. The increase in rotational speed makes the flow rate of baseline testing rise, and the amount of oil splashed to the oil-collecting pipe is greatly increased, resulting in a larger increase in oil volume. There is a critical speed between $400 \mathrm{r} / \mathrm{min}$ and $530 \mathrm{r} / \mathrm{min}$, beyond which the oil can climb to the top of the oil-guiding cylinder in large quantities; if not, the continuous oil supply cannot be realized.

2. The amount of oil passing through the target area increases with the oil level. The higher the oil level height, the more oil is splashed into the oil-collecting tube from the gear surface. From the oil supply at the top of the oil-guiding cylinder, the oil supply increases when the oil level rises, but the amount of oil is not significantly elevated. At this point, the amount of oil flowing through the oil-jet hole has reached 
saturation point. Balancing the resisting moment and the flow rate, the oil level height $H=55 \mathrm{~mm}$ is the best choice.

3. The difference in flow rate caused by the pitch angle and the roll angle is mainly due to gravity and rotation direction. When the direction of oil throwing is inclined to the gravity direction, the splash of oil volume is higher. When the rotor shaft is rotating, the splash of oil volume is higher as the oil-jet hole moves from high to low than that of moving from low to high.

Author Contributions: Conceptualization, M.Y. and D.Y.; methodology, X.C.; software, L.X.; validation, L.X.; formal analysis, L.X.; investigation, X.C.; resources, Y.D.; data curation, X.C.; writingoriginal draft preparation, X.C.; writing-review and editing, X.Z.; visualization, X.Z.; supervision, Y.D.; project administration, Y.D.; funding acquisition, Y.D. All authors have read and agreed to the published version of the manuscript.

Funding: This research was funded by the National Defense Preliminary Research Project of China, Grant Number KY-1044-2020-0657.

Acknowledgments: We would like to express our thanks to the editors of Aerospace and the anonymous reviewers for their work in processing this article.

Conflicts of Interest: The authors declare no conflict of interest.

\section{References}

1. Seetharaman, S.; Kahraman, A.; Moorhead, M.D.; Petry-Johnson, T.T. Oil Churning Power Losses of a Gear Pair: Experiments and Model Validation. J. Tribol. 2009, 131, 022202. [CrossRef]

2. Neurouth, A.; Changenet, C.; Ville, F.; Octrue, M.; Tinguy, E. Experimental Investigations to Use Splash Lubrication for HighSpeed Gears. J. Tribol. 2017, 139, 061104. [CrossRef]

3. Casseau, V.; Espinoza, D.E.R.; Scanlon, T.J.; Brown, R.E. A Two-Temperature Open-Source CFD Model for Hypersonic Reacting Flows, Part Two: Multi-Dimensional Analysis. Aerospace 2016, 3, 45. [CrossRef]

4. Youssefi, M.R.; Knight, D. Assessment of CFD Capability for Hypersonic Shock Wave Laminar Boundary Layer Interactions. Aerospace 2017, 4, 25. [CrossRef]

5. Samad, A.; Villeneuve, E.; Morency, F.; Volat, C. A Numerical and Experimental Investigation of the Convective Heat Transfer on a Small Helicopter Rotor Test Setup. Aerospace 2021, 8, 53. [CrossRef]

6. Moshammer, T.; Mayr, F.; Kargl, K.; Honeger, C. Simulation of Oil Flow in Gear Box Housing. SAE Tech. Pap. Ser. 2006, 1, 1574. [CrossRef]

7. Concli, F.; Torre, A.D.; Gorla, C.; Montenegro, G. A New Integrated Approach for the Prediction of the Load Independent Power Losses of Gears: Development of a Mesh-Handling Algorithm to Reduce the CFD Simulation Time. Adv. Tribol. 2016, 2016, 2957151. [CrossRef]

8. Concli, F.; Gorla, C. Numerical modeling of the power losses in geared transmissions: Windage, churning and cavitation simulations with a new integrated approach that drastically reduces the computational effort. Tribol. Int. 2016, 103, 58-68. [CrossRef]

9. Concli, F.; Gorla, C. Numerical modeling of the churning power losses in planetary gearboxes: An innovative partitioning-based meshing methodology for the application of a computational effort reduction strategy to complex gearbox configurations. Lubr. Sci. 2017, 29, 455-474. [CrossRef]

10. Liu, H.; Jurkschat, T.; Lohner, T.; Stahl, K. Determination of oil distribution and churning power loss of gearboxes by finite volume CFD method. Tribol. Int. 2017, 109, 346-354. [CrossRef]

11. Liu, H.; Arfaoui, G.; Stanić, M.; Montigny, L.; Jurkschat, T.; Lohner, T.; Stahl, K. Numerical modelling of oil distribution and churning gear power losses of gearboxes by smoothed particle hydrodynamics. Proc. Inst. Mech. Eng. Part J. J. Eng. Tribol. 2018, 233, 74-86. [CrossRef]

12. Liu, H.; Jurkschat, T.; Lohner, T.; Stahl, K. Detailed Investigations on the Oil Flow in Dip-Lubricated Gearboxes by the Finite Volume CFD Method. Lubricants 2018, 6, 47. [CrossRef]

13. Hu, X.; Jiang, Y.; Luo, C.; Feng, L.; Dai, Y. Churning power losses of a gearbox with spiral bevel geared transmission. Tribol. Int. 2019, 129, 398-406. [CrossRef]

14. Jiang, Y.; Hu, X.; Hong, S.; Li, P.; Wu, M. Influences of an oil guide device on splash lubrication performance in a spiral bevel gearbox. Tribol. Int. 2019, 136, 155-164. [CrossRef]

15. Hu, X.; Wang, A.; Li, P.; Wang, J. Influence of dynamic attitudes on oil supply for bearings and churning power losses in a splash lubricated spiral bevel gearbox. Tribol. Int. 2021, 159, 106951. [CrossRef]

16. Changenet, C.; Velex, P. A Model for the Prediction of Churning Losses in Geared Transmissions-Preliminary Results. J. Mech. Des. 2006, 129, 128-133. [CrossRef] 
17. Changenet, C.; Velex, P. Housing Influence on Churning Losses in Geared Transmissions. J. Mech. Des. 2008, $130,062603$. [CrossRef]

18. Changenet, C.; Leprince, G.; Ville, F.; Velex, P. A Note on Flow Regimes and Churning Loss Modeling. J. Mech. Des. 2011, 133, 121009. [CrossRef]

19. Quiban, R.; Changenet, C.; Marchesse, Y.; Ville, F.; Belmonte, J. Churning losses of spiral bevel gears at high rotational speed Proc. Inst. Mech. Eng. Part J. J. Eng. Tribol. 2019, 234, 172-182. [CrossRef]

20. Dai, Y.; Ma, F.; Zhu, X.; Ouyang, B. Development of an analytical model to estimate the churning power losses of a spiral bevel gear. Tribol. Int. 2020, 151, 106536. [CrossRef]

21. Lu, F.; Wang, M.; Bao, H.; Huang, W.; Zhu, R. Churning power loss of the intermediate gearbox in a helicopter under splash lubrication. Proc. Inst. Mech. Eng. Part J. J. Eng. Tribol. 2021. [CrossRef]

22. Wang, Y.; Niu, W.; Wei, S.; Song, G. Influence of spin flow on lubricating oil jet-Design method of oil spray parameters to high speed spur gears. Tribol. Int. 2015, 92, 290-300. [CrossRef]

23. Wang, Y.; Song, G.; Niu, W.; Chen, Y. Influence of oil injection methods on the lubrication process of high speed spur gears. Tribol. Int. 2018, 121, 180-189. [CrossRef]

24. Wang, Y.; Song, G.; Niu, W.; Chen, Y. Optimized design of spray parameters of oil jet lubricated spur gears. Tribol. Int. 2018, 120, 149-158. [CrossRef]

25. Dai, Y.; Wu, W.; Zhou, H.B.; Zhang, J.; Ma, F.Y. Numerical Simulation and Optimization of Oil Jet Lubrication for Rotorcraft Meshing Gears. Int. J. Simul. Model. 2018, 17, 318-326. [CrossRef]

26. Dai, Y.; Jia, J.; Ouyang, B.; Bian, J. Determination of an Optimal Oil Jet Nozzle Layout for Helical Gear Lubrication: Mathematical Modeling, Numerical Simulation, and Experimental Validation. Complexity 2020, 2020, 2187027. [CrossRef]

27. Dai, Y.; Ma, F.; Zhu, X.; Su, Q.; Hu, X. Evaluation and optimization of the oil jet lubrication performance for orthogonal face gear drive: Modelling, simulation and experimental validation. Energies 2019, 12, 1935. [CrossRef]

28. Zhu, X.; Dai, Y.; Ma, F.; Ouyang, B. Mathematical modeling and numerical simulation for determining an optimized oil jet layout for spiral bevel gear lubrication. Proc. Inst. Mech. Eng. Part J. J. Eng. Tribol. 2021, 235, 611-628. [CrossRef]

29. Fondelli, T.; Andreini, A.; Da Soghe, R.; Facchini, B.; Cipolla, L. Numerical Simulation of Oil Jet Lubrication for High Speed Gears. Int. J. Aerosp. Eng. 2015, 2015, 752457. [CrossRef]

30. Fondelli, T.; Andreini, A.; Da Soghe, R.; Facchini, B.; Cipolla, L. Volume of fluid (VOF) analysis of oil-jet lubrication for high-speed spur gears using an adaptive meshing approach. In Proceedings of the ASME Turbo Expo 2015: Turbine Technical Conference and Exposition, Montreal, Quebec, QC, 15-19 June 2015. [CrossRef]

31. Massini, D.; Fondelli, T.; Facchini, B.; Tarchi, L.; Leonardi, F. High Speed Visualizations of oil Jet Lubrication for Aero-engine Gearboxes. Energy Procedia 2016, 101, 1248-1255. [CrossRef]

32. Yin, M.; Xu, L.J.; Dai, Y.; Yang, D.; Zhu, X. Flow Characteristics of Oil-Guiding Splash Lubrication: Simulation and Experiment Studies. Int. J. Simul. Model. 2021, 20, 363-374. [CrossRef]

33. Wang, T.; Guo, Y.; Wang, G.; Wang, X. Detection and analysis of metal scrap in lubricating oil based on wear fault of spindle bearing of turboshaft engine. Vibroeng. Procedia 2021, 38, 32-37. [CrossRef]

34. Wróblewski, P. Analysis of Torque Waveforms in Two-Cylinder Engines for Ultralight Aircraft Propulsion Operating on 0W-8 and 0W-16 Oils at High Thermal Loads Using the Diamond-Like Carbon Composite Coating. SAE Int. J. Engines 2021, 15, 2022. [CrossRef]

35. Wróblewski, P.; Koszalka, G. An Experimental Study on Frictional Losses of Coated Piston Rings with Symmetric and Asymmetric Geometry. SAE Int. J. Engines 2021, 14, 853-866. [CrossRef] 